\title{
Reconstruction Parate Execution of Liability Rights and Roles the Parties in the Determination of Auction Price Limit Value Justice Based Warranty
}

\author{
Mochamad Mochtar; Abdul Rachmad Budiono; Iwan Permadi; Siti Hamidah \\ Doctor of Law Science Program, Faculty of Law, University of Brawijaya Malang, Indonesia \\ http://dx.doi.org/10.18415/ijmmu.v8i2.2366
}

\begin{abstract}
Research on Legal Reconstruction of Mortgage Rights and the Role of the Parties as Determining the Price Limit Value at the Parate Auction for Execution of Collateral Goods Bound to Mortgage, departs from the issues discussed, namely how the parate reconstruction of mortgage execution and the role of the parties in determining the limit value of the auction price of goods justice based guarantees? The purpose of this research is to analyze and find the reconstruction of the execution parate of mortgage rights and the role of the parties in determining the limit value of the auction price of collateral based on justice. The research method uses normative legal research, with a statutory approach (statute approach) and a case approach (case approach). Sources of legal materials used consist of primary, secondary and tertiary legal materials, while the analysis of legal materials is carried out in a descriptive qualitative manner. Based on the results of the research, it can be concluded that the parate reconstruction of mortgage execution must be based on justice, meaning that execution through parate execution based on the provisions of Article 6 of the Mortgage Rights Law, must also be balanced with other prerequisites that must be passed in order to minimize the arising of arbitrariness. The role of the parties in determining the limit value of the collateral auction price will be well realized if in determining the limit value determined based on the results of the appraiser's assessment, where the auction limit value must be as low as the liquidation value so that the auction office has the authority to reject the auction request. submitted by the seller, if it does not comply with the standards specified in the Minister of Finance Regulation No.27 / PMK.06 / 2016.
\end{abstract}

Keywords: Reconstruction; Parate Execution; Mortgage; Auction Limit Value

\section{Introduction}

The background for the inclusion of execution parates in Law Number 4 of 1996 concerning Mortgage Rights for land and objects related to land (hereinafter referred to as the Mortgage Rights Law) cannot be separated from the context of the birth of the law. One of the fundamental things is the need to provide adequate protection for the mortgage right holder, in this case the creditor as the credit provider. 
Rights Security rights give priority or precedence to the holder (droit de preference). In the body of the Law on Mortgage, it is emphasized in Article 1 point 1 and Article 20 paragraph (1). If the debtor is in default (default), the creditor holding the mortgage has the right to sell the land that is encumbered with the Mortgage through a public auction with the right to precede other creditors, and the execution of the mortgage is easy and certain (parate exceusie). Article 6 of the Mortgage Rights Law gives rights to Mortgage holders to parate execution. This means that the Mortgage holder not only obtains approval from the mortgage provider, but also does not need to ask for a decision from the local court if he will carry out the execution of the Mortgage which is the collateral for the debtor's debt in the event the debtor is default. Holders of Mortgage Rights can come directly and ask the Head of the Auction Office to carry out an auction for the object of the Mortgage Rights concerned. ${ }^{1}$ This means that the execution parate is the most powerful and fastest weapon in eradicating bad credit, by executing (auctioning) collateral without court intervention.

Thus, the execution can be carried out by executing the grosse deed, in which the Certificate of Mortgage contains the order of "FOR JUSTICE BASED ON ALMIGHTY GOD", so that it has the same executorial power as a court decision and has obtained permanent legal force. One of the features in terms of legal protection provided by the Mortgage Rights Law to creditors is manifested in the execution of the object of the guarantee of the mortgage if the debtor defaults.

Parate execution is an execution which is carried out without having an executorial title (Grosse Akta Notary, Judge's Decision) is by means of parate execution (direct execution), that is, the holder of the Mortgage with a promise to sell on his own power can exercise his rights directly without going through a judge's decision or Grosse Deed of Notary "2, that was the opinion of Sri Soedewi Masjchoen Sofwan.

According to Herowati Poesoko's view, that the formation of an execution parate institution in the Mortgage Rights Law, in addition to providing a means that is deliberately held for creditors who hold the first Mortgage Rights to get their receivables back easily and cheaply (with the intention of breaking through the formalities of procedural law), on the other hand the purpose of forming an execution parate in the Mortgage Rights Law also intends to strengthen the position of the creditors of the first Mortgage holder on the parties who get rights from it. ${ }^{3}$

In order to protect the interests of the first Mortgage holder (creditor) in accordance with the above description of understanding, it must be considered that the right / authority to sell on his own power is obtained by the creditor / first Mortgage holder not solely because of agreement, but also because the law stipulates this (after being agreed). This is to further emphasize that the law provides guarantees in concrete rules as a binding norm that the "right to sell on one's own power" is the main means for the first creditors / mortgage holders to get convenience in order to get back their receivables.

The implementation of the execution parate cannot be separated from the debt settlement scheme which begins with a credit agreement between the creditor and the debtor through a mortgage institution. ${ }^{4}$ However, in its implementation, it often encounters obstacles as evidenced by the emergence of several lawsuits from the debtor as the owner of the land which is used as collateral as a mortgage, and because of that it needs further investigation.

\footnotetext{
${ }^{1}$ Sutan Remy Sjahdeini, Hak Tanggungan: Asas-Asas, Ketentuan-Ketentuan Pokok dan Masalah yang Dihadapi Oleh Perbankan (Suatu Kajian Mengenai Undang-Undang Hak Tanggungan), Edisi ke-2, Cetakan ke-1, Alumni, Bandung, 1999, hlm. 11-34.

${ }^{2}$ Sri Soedewi Masjchoen Sofyan, Hukum Jaminan di Indonesia: Pokok-Pokok Hukum Jaminan dan Jaminan Perorangan, Liberty, Yogyakarta, 1980, hlm. 32

${ }^{3}$ Herowati Poesoko, Parate Executie Obyek Hak dan Kesesatan Penalaran dalam Undang-Undang Hak Tanggungan, Cetakan ke-2, LaksBang Pressindo, Yogyakarta, 2008, hlm. 282.

${ }^{4}$ Lihat Pasal 10 ayat (1), dan Pasal 18 ayat (1) UU Nomo4 Tahun 1996 tentang Hak Tanggungan atas tanah dan benda-benda yang berkaitan dengan tanah
} 
The problems discussed in this article are how to reconstruct the execution parate of mortgage rights and what is the role of the parties in determining the limit value of the auction price of collateral based on justice?

The research method used is normative legal research, with a statute approach and a case approach. The sources of legal materials used include primary legal materials, secondary legal materials and tertiary legal materials, while the analysis of legal materials is carried out in a descriptive qualitative manner.

\section{B. Discussion}

\section{Reconstruction of mortgage execution parate}

Legal principles are born to protect and regulate human interests, so that order or stability will be created and are expected, including preventive and repressive measures in the event of conflicts or disturbances of interests. ${ }^{5}$

Jeremy Bentham argues that the goal of law is to achieve the greatest happiness for as many people as possible (the greatest happiness of the greatest number). Bentham also stated that the purpose of legislation is to produce happiness for the community, or at least must try to achieve 4 (four) goals, namely: ${ }^{6}$

a. To provide subsistence (to provide a living).

b. To provide abundance (to provide abundant food).

c. To provide security (to provide protection).

d. To attain equity (to achieve togetherness).

In the aspect of justice and benefit, actually these values have existed and have even been traditionally attached to the law since the past, only the aspect of legal certainty is born later. The value of legal certainty is of course not just born out of the blue, but is born based on the conditions in which society is in dire need of an increasingly complex social context.

One of the objectives of law is to create legal certainty, namely the firmness of the application of the law itself where the law applies to all people without discrimination. Legal certainty is an absolute requirement for the implementation of the rule of law in a rule of law. A new state is declared as a rule of law if the country adheres to the concept of rule of law, equality before the law, and a state based on a constitution. Legal supermasi means that all existing problems are returned to the law itself. In addition, between legal certainty, justice, and legal benefits, the actual interconnection or interrelation with legal regulations, legal changes, law enforcement, and the expectations of society for the functioning of the law. ${ }^{7}$

In line with the legal objectives, one of which is to realize the value of legal certainty, the position of the execution parate institution is clearly recognized and regulated in the Mortgage Law. However, the reality is that in practice and the course of the execution parate institutions cannot be used properly. In addition, there are implementing regulations that are not in sync with the implementation of execution

\footnotetext{
${ }^{5}$ Sudikno Mertokusumo, Teori Hukum, Cahaya Atma Pustaka, Yogyakarta, 2012, hlm. 17.

${ }^{6}$ Teguh Prasetyo, Filsafat, Teori dan Ilmu Hukum (Pemikiran Menuju Masyarakat yang Berkeadilan dan Bermartabat), PT. Raja Grafindo, Jakarta, 2012, hlm. 111-112.

${ }^{7}$ Fachmi, Kepastian Hukum Mengenai Putusan Batal Demi Hukum dalam Sistem Peradilan Pidana Indonesia, Ghalia Indonesia, Jakarta, 2011.
} 
through execution parate institutions, such as the Supreme Court Decision Number: 3021 K / Pdt / 1984 dated January 30, 1986, and the issuance of SEMA Number 7 of 2012 which basically states that even though the creditor already holds the Mortgage, which means the value of execution parate, but if the creditor is going to carry out the execution, it must go through the fiat of the Head of the District Court, not allowed to go directly to the Auction Office, instead dwarfing the position of the parate institution for executing mortgage rights.

Although the Supreme Court Decision can be used as jurisprudence, when viewed from the time the Mortgage Law was born in the Indonesian legal system, court decisions only have binding power for the case being tried and the parties to the dispute in the case. ${ }^{8}$

To be able to use that power, the questions required must be the same; claims must be based on the same reasons; and must be proposed by the same party and against the same parties in the same relationship". Thus, in fact jurisprudence can also be used as a source of law that has a relatively binding power, except for the decisions of the State Administrative Court and the decisions of the Constitutional Court.

Thus, if the law does not provide regulations that can be used to settle the case, the judge can form his own provisions / regulations (legal discovery). A judge's decision that contains a provision / regulation can become the basis for the decision of another judge / later to try similar cases and the judge's decision then becomes a source of law for the court. ${ }^{9}$

SEMA is not a legal product that binds outward, the argument can be seen in Article 8 paragraph (1) of Law No. 12 of 2011 concerning the Formation of Laws and Regulations which states that: "Types of Legislation other than those referred to in Article 7 paragraph (1) includes regulations stipulated by the People's Consultative Assembly, the People's Representative Council, the Regional Representative Council, the Supreme Court, the Constitutional Court, the Supreme Audit Agency, the Judicial Commission, Bank Indonesia, Ministers, agencies, institutions, or commissions of the same level as established by law or Government at the behest of law, Provincial Regional People's Representative Council, Governor, Regency / City Regional People's Representative Council, Regent / Mayor, Village Head or equivalent ". Furthermore, in Article 8 paragraph (2) of Law No. 12 of 2011 concerning the Formation of Laws and Regulations it is stated that: "Legislation as referred to in paragraph (1) is recognized for its existence and has binding legal force as long as it is ordered by the Legislation. which is higher or formed based on authority".

Thus, in fact legally the binding strength of SEMA Number 7 of 2012 cannot be used as a support, apart from being not a legal product that has general binding power, it also has an interpretation that actually negates the regulations that are above it. This also contradicts the hierarchy of legislation and the principle of lex superior derogat legi inferior.

Seeing these conditions and facts, it is important to formulate solution steps so that the value of legal certainty in the Mortgage Law is related to parate execution. This legal certainty is of course related to aspects of benefit and justice primarily for creditors in the context of getting repayment if the debtor defaults / breaches his promise, among others by strengthening the position of the execution parate institution by making implementing regulations.

According to the author's opinion, the provisions of Article 6 which regulate the provisions of the execution parate institution in the Mortgage Law, still have weaknesses, namely the absence of implementing regulations that can clarify both in substance and in their implementation. There are several

\footnotetext{
${ }^{8}$ Lihat Pasal 21 AB dan Pasal 1917 KUHPerdata

${ }^{9}$ Purnadi Purbacaraka dan Soerjono Soekanto, Perundangan-Undangan dan Yurisrprudensi, Alumni, Bandung, 1979 , hlm. 56.
} 
implementing regulations that have been in place to follow up on the provisions of the execution parate in accordance with Article 6 of the Mortgage Law. In particular, BUPLN has issued Circular Letter Number: SE-21 / PN / 1998 concerning Guidelines for Implementing Article 6 of the Mortgage Law. In the Circular Letter Number: SE-21 / PN / 1998 point 1 states that: "... The sale was not forced, but was an act of implementing the agreement by the parties. Therefore, there is no need to hesitate any longer to serve auction requests from banks for objects of mortgage rights under Article 6 of the UUHT ". Furthermore, number 3 of the Circular Letter states: "... Auction of mortgage objects based on Article 6 of the UUHT is classified as a voluntary auction". In addition, BUPLN has also issued a Circular Letter Number: SE-23 / PN / 2000 where it is stated in point 1 letter a and letter e that: "..... The auction of mortgage rights as referred to in Article 6 of the UUHT does not require a debtor's approval for the implementation of the auction. ". ${ }^{10}$

In line with the phrase "the right to sell the object of the Mortgage on one's own power through a public auction", the auction house regulation further emphasizes that the executor of this execution is the Office of the Auction Hall, not the Head of the District Court as the execution through the executorial title. This is because, once again, as previously explained, the philosophical goal of the birth of an execution parate institution is the aspect of convenience, cheapness and without court interference in the execution of the object of guarantee.

Prior to the issuance of SEMA No. 7/2012, the Supreme Court's stance in terms of implementing parate executions could be said to be neutral by maintaining its opinion that executions through execution parate institutions according to Article 6 of the Mortgage Rights Law are legally valid. It is worth asking then, why did the Supreme Court's attitude change by boldly issuing SEMA No. 7/2012 which is substantially contradicting the provisions of Article 6 of the Mortgage Rights Law?

The most important thing is that the execution parate as referred to in Article 6 of the Mortgage Law still requires confirmation of its definition and substance. In the execution of the execution parate, there is still a dualism of interpretation in terms of who the executor has the authority, whether the Head of the Auction Hall, or the Head of the District Court as per Article 200 HIR and Article 224 HIR. Examining the issue of authority, at least it can be seen again the construction of Article 6 of the Mortgage Law, where it states that: "If the debtor is in default, the first Mortgage holder has the right to sell the object of the Mortgage on his own power through a public auction and take repayment of his receivables from the sale proceeds. such ".

From the above norms, it can be seen that the phrase "having the right to sell an object of Mortgage on one's own power through a public auction" is a formal law. The meaning is that with the parate execution doctrine, the one who has the authority to execute is the Head of the Auction Center, which in this case is based on orders from the mortgageee (creditor). This substance distinguishes execution based on Article 6 of the Mortgage Rights from the execution of the grosse deed (executorial title) as in mortgages, where in the execution of the mortgage (grosse deed), the authority to carry out the execution is the Chairman of the District Court.

There are several things that must be considered in the parate reconstruction of the execution of mortgage rights in order to create justice or balance between the two parties (creditors and debtors), including in public tenders the limit price proposed by the creditor (provider of mortgage) is often far below the market price of object being auctioned. Often the creditor in setting the limit price only refers to the repayment value that must be paid by the creditor to him, resulting in a very large difference between the actual value of the auction object and the limit price. This greatly affects the sale value, which often the auction object is successfully sold above the initial limit price, and is still very far from its

\footnotetext{
${ }^{10}$ Herowati Poesoko, Op., Cit, hlm. 244.
} 
true value. In fact, clear signs have been given in Regulation of the Minister of Finance Number 27 / PMK.06 / 2016 concerning Instructions for Implementation of Auctions which provide legal construction related to limit values in particular related to the auction for execution of fixed goods in the form of land / and buildings.

If this is implemented properly and correctly, it will certainly produce the best results obtained by creditors in terms of credit repayment through auction sales results and debtors in terms of getting a return from the difference in credit repayment and the proceeds from the sale of the auction object. The expected justice will certainly make the impetus for taking legal remedies that are "hindering" which is usually done by debtors to decrease or can be minimized.

Furthermore, before a creditor attempts execution through an execution parate agency, mediation between the two parties concerned, namely the creditor and the debtor, should first be carried out. This includes finding a middle ground where when a debtor's default occurs, the recipient of the mortgage (creditor) seeks other means, such as debt restructuring, or payment delays.

It is necessary to make a provision that contains the grace period or limit in terms of carrying out parate execution of Article 6 of the Mortgage Law. This is based on the fact that often the creditor delays the execution of this execution for a very long time, even though the debtor is clearly known to no longer have the ability to pay. This condition can become dangerous although the debtor will benefit at some point in several ways. The benefits of this long period of time can be used by debtors to maximize their search for ways to pay arrears and repay loans. However, the actual length of time can be a double-edged sword, which at a certain point is very detrimental to the debtor. Logically, if the creditor postpones the execution of the collateral object, even though the debtor is known to have no ability to pay, the repayment obligation is getting bigger. The calculation of the amount of interest, fines and principal debt is bigger when compared to before, meanwhile, there is often a big difference between the initial loan disbursement and the value of the collateral object.

This, of course, for the debtor will feel very disadvantaged, because when it is known that the debtor does not have the ability to pay or there has been a default, the object of the guarantee is executed, of course the debtor will get the remaining profit from the difference between the auction results and settlement. Of course it is impossible and baseless if the creditor deliberately allows this problem to drag on if the difference between the initial credit value and the object value of the collateral is not too far away, because of course it will be even more detrimental. Therefore, fraudulent practices to take advantage in this way must be answered with strict rules, so that there is no arbitrariness in the case of parate executions in accordance with Article 6 of the Mortgage Law.

In Article 1 number 4 of the Financial Services Authority Regulation Number 11 / POJK.03 / 2015 concerning Prudential Provisions in the Context of National Economic Stimulus for Commercial Banks, it is stated that Credit Restructuring is an effort made by Banks in lending activities for debtors who have difficulty meeting obligations, which are carried out, among others, through:

a. reduction in Credit interest rates;

b. extension of the Credit term;

c. reduction in arrears Credit interest;

d. reduction in arrears of Credit principal;

e. additional Credit facilities; and / or

f. Credit conversion into temporary equity participation.

The contents of the Mortgage Law, especially in the context of execution, do not provide clarity and even multiple interpretations, and do not reflect legal certainty. Legal certainty is of course important, 
because law has the task of creating order in society. Legal certainty is a feature that cannot be separated from law, especially for written legal norms. Law without the value of legal certainty will lose its meaning because it can no longer be used as a code of conduct for everyone.

The reconstruction of the execution parate is an effort to make a fundamental change related to how to provide a strict and firm definition in the context of the definition of parate for executing mortgage rights.

\section{The Role of the Parties in Determining the Limit Value of the Auction Price of Collateral Based on Justice}

The Indonesian people argue that auctions are always related to the court, even though in reality it cannot be denied that most of the auction process is carried out because of the court's decision on the party that loses in a case. The reluctance of the Indonesian people to conduct an auction results in what the government hopes, namely that the community does not take advantage of the auction institution, so that the benefits of the auction cannot be felt by the community.

By selling by auction there are several benefits to the community. Some of the benefits that can be obtained from the auction are: fast and efficient, safe, fair, realizing a fair price because it uses the bidding system and provides legal certainty because it is carried out by auction officials and minutes of auction are made as authentic deeds used for the process of transferring names to auction winners. Fast and efficient, because before the auction process is carried out it is always preceded by an announcement of the auction so that participants can gather at the time the auction is held. It is safe, because in the auction process it is witnessed by the leadership and carried out by Public Officials appointed by the Government who are independent. Fair, this is because it is open or transparent and objective. In the implementation of the auction, there are several parties involved, namely Buyers, Sellers, Auction Officials (formerly known as the auctioneer), and auction supervisors (formerly known as Superintendent).). ${ }^{11}$

Auction as a legal institution has the role of creating the value of an item or changing the form of a product into an amount of money according to its objective value. An auction institution that exists within the legal system of a society has several functions including:

a. To meet the needs of auction sales, which are regulated in statutory regulations.

b. To fulfill or implement court decisions and dispute resolution institutions based on law in the context of law enforcement.

c. To meet the needs of the business world, it is possible for producers or owners of private objects to conduct auction sales.

Decree of the Minister of Finance Number: 27 / PMK.06 / 2016 regarding the instructions for the implementation of Auction, formulating what is meant by Auction, namely the sale of goods open to the public either directly or through electronic media by means of verbal and / or written price quotes preceded by an effort to gather enthusiasts.

At the time of the auction, the auction activity is the responsibility of the auctioneer (auction official). Sales made through an auction must be preceded by an Auction Announcement made by the Seller through a newspaper published at the location of the goods to be auctioned. Then the seller who

\footnotetext{
11 Naskah Akademik Rancangan Undang-Undang Lelang, Departemen Keuangan Republik Indonesia Direktorat Jenderal Piutang dan Lelang Negara, Biro Hukum-Sekretariat Jenderal, (Jakarta: 18 Februari 2005), hlm. 4.
} 
intends to make sales through an auction sends a written bid application letter addressed to the Head of KP2LN or the Head of the Auction Hall and accompanied by the tender requirements documents. Meanwhile, if you want to become a participant in the auction, each participant is required to deposit the Bid Security Deposit which is deposited through an account in accordance with the auction announcement or submitted directly to the Treasurer Receiving KP2LN / Auction Officer.

In every auction, the Seller is required to set a Limit Price which is based on an accountable valuation approach, except for the implementation of the Non-Voluntary Execution of movable goods, the Seller may not require a Limit Price. Limit prices can be open or closed according to the wishes of the Seller. Auction Offer can be carried out directly or indirectly through oral, written, or written, which is then continued orally in the case of the highest bid if it has not reached the Limit Price.

The seller or the party whose interest is represented by the seller has an interest in obtaining a price with the maximum value, and is justice for the owner of the goods to obtain the proceeds from the disbursement of the goods, in which the rights of the owner and the competent authorities are guaranteed. This reduces the risk of civil suit regarding an unreasonable auction price, which in turn reduces the possibility of the auction buyer's rights being compromised by the cancellation of an auction that has been executed by a court decision based on an unreasonable auction price claim because it is too low.

In the implementation of the auction, especially the execution auction, the potential for lawsuits is very high. The total claims submitted to the DJKN / KPKNL (based on the State Wealth Media Bulletin No. 14 of the Year IV / 2013) are 2,458 and more than 1,500 are claims from the auction for execution of Article 6 Mortgage. ${ }^{12}$ The lawsuit / rebuttal is separately submitted before the auction and after the auction. The claim before the auction is intended by the plaintiff to delay the implementation of the auction, while the post-auction claims / rebuttals have very various motives behind it.

Lawsuits generally arise when someone is dissatisfied. As a rule of law / rechtstaat, every citizen who feels his rights have been violated, has the right to file a lawsuit / rebuttal to the court as a channel for his violated rights. Most of the complaints against the auction were due to illegal acts (PMH).

The problem is that there are often different perceptions regarding limit pricing. The actions of determining the low limit value at the execution auction can be used as a basis for determining the existence of an illegal act.

In determining the auction limit value below the selling value of the tax object (NJOP), if the collateral object has frequently been re-auctioned but there are still no enthusiasts, then the seller can carry out the auction below the NJOP value of the guarantee object, but the seller must notify the debtor or the collateral owner if the collateral object will be auctioned with a limit value below the NJOP, but before that, at least 3 months must be given to the debtor to sell the collateral object himself if it can be sold at a higher price to pay off the debtor's debt to the creditor. According to the author's analysis, this must be done in order to avoid a lawsuit on the grounds of unlawful acts by the debtor.

Minister of Finance Regulation No.27 / PMK.06 / 2016 concerning Instructions for Conducting Auctions, stipulates that the limit value must be determined by the Seller based on the assessment results of the appraiser, where the auction limit value must be as low as the liquidation value so that the auction office has the authority to reject auction application submitted by the Seller, if it does not comply with the predetermined standards. According to the author's analysis, this is the right step, so that it can better guarantee the achievement of justice for the parties, especially the debtor as the party whose object of

12 https://media.neliti.com/media/publications/119824-ID-kajian-yuridis-pembatalan-lelang-eksekus.pdf, Ria Desmawati Rianto, kajian yuridis pembatalan lelang eksekusi karena nilai limit rendah, diakses pada tanggal 10 Desember 2020, Jam 09.30. 
guarantee will be auctioned. Thus the role of the parties in determining the limit value of the auction price of collateral based on justice can be realized properly.

\section{Conclusion}

Based on the description above, several conclusions can be drawn as follows:

1. Parate reconstruction of the execution of mortgage rights must be based on justice (balances of justice), meaning that even if the creditor has the right to carry out execution through parate execution as in Article 6 of the Mortgage Rights Law, it must also be balanced with other prerequisites that must be passed in order to minimize the emergence of arbitrariness-authority.

2. The role of the parties in determining the limit value of the auction price of collateral based on justice can be realized properly if the determination of the limit value is determined based on the appraiser's assessment, where the auction limit value must be as low as the liquidation value so the auction office has the authority to reject the auction application submitted by the Seller, if it does not comply with the standards stipulated in the Regulation of the Minister of Finance No.27 / PMK.06 / 2016 concerning Guidelines for Auction Implementation.

\section{References}

\section{Book:}

Fachmi, (2011), Legal Certainty Regarding the Decision to Cancel for the sake of the Law in the Indonesian Criminal Justice System, Ghalia Indonesia, Jakarta.

Masjchoen Sofyan, Sri Soedewi, (1980), Guarantee Law in Indonesia: Principles of Personal Guarantee and Guarantee Law, Liberty, Yogyakarta.

Mertokusumo, Sudikno, (2012), Legal Theory, Atma Pustaka's Light, Yogyakarta.

Academic Paper of the Draft Law on Auction, Ministry of Finance of the Republic of Indonesia, Directorate General of Receivables and State Auctions, Legal Bureau-Secretariat General, Jakarta: 18 February 2005.

Poesoko, Herowati, (2008), Parate Executie Object Rights and Reasoning Errors in the Mortgage Rights Law, 2nd Printing, LaksBang Pressindo, Yogyakarta.

Prasetyo, Teguh, (2012), Philosophy, Theory and Law (Thinking Towards a Just and Dignified Society), PT. Raja Grafindo, Jakarta.

Remy Sjahdeini, Sutan, (1999), Mortgage: Principles, Basic Provisions and Problems Faced by Banks (A Study of the Mortgage Law), 2nd Edition, 1st Edition, Alumni, Bandung.

Subekti, R and R. Tjitrosudibio, (2000), Civil Code, Publisher Pradnya Paramita, Jakarta. 


\section{Journals, Papers, Newspapers, Websites:}

Ria Desmawati Rianto, juridical study of the cancellation of the execution auction due to a low limit value, https://media.neliti.com/media/publications/119824-ID-kajian-yuridis-pemb Cancellationlelang-eksekus.pdf, accessed on 10 December 2020 , 09.30 hours

\section{Constitution:}

Law of the Republic of Indonesia Number 4 of 1996 concerning Mortgage Rights on land and objects related to land.

Minister of Finance Regulation No.27 / PMK.06 / 2016 concerning Guidelines for Bid Implementation.

\section{Copyrights}

Copyright for this article is retained by the author(s), with first publication rights granted to the journal.

This is an open-access article distributed under the terms and conditions of the Creative Commons Attribution license (http://creativecommons.org/licenses/by/4.0/). 